\title{
Kamu Yönetişiminin Uzamı ve Aracı Olarak Nesnelerin İnterneti Politikaları Üzerine Bir Değerlendirme
}

\author{
Serhat KAYMAS*
}

Öz

Bu çalışma, isminde de yer aldığı üzere, kamu politikalarının uzamı ve aracı olarak nesnelerin internetini karşılaştırmalı bir siyasa analizi üzerinden özellikle gelişmekte olan ülkeler bağlamında ele almaktadır. Ülkelerin bilgi toplumuna dönüşüm süreçlerinin önemli bir bileșeni olarak nesnelerin interneti ekosistemini, gelișmiş ülkelere göre sosyal, siyasal, kültürel ve ekonomik bağlamlar öncelikli olmak üzere yapısal farklılıkları bulunan gelişmekte olan ülkeler perspektifinden bakarak değerlendirmek anlamlı bir çaba olarak değerlendirilmelidir. Bu doğrultuda çalışma, nesnelerin interneti ve bileșen bilgi teknolojilerini Türkiye örneğinde bir "fırsatlar" ve "tehditler" alanı olarak tartışmaktadır. Çalışmanın sonunda, Türkiye için nesnelerin interneti yönetişimi bağlamında bir dizi öneri geliștirilmiş̦tir.

Anahtar Sözcükler: Nesnelerin İnterneti, Bilgi Toplumu, Bilişsel Kapitalizm, Bilgi ve İletişim Teknolojileri, Yönetişim.

\section{An Assessment on the Internet of Things as Both a Space and an Apparatus of the Public Policies}

\section{Abstract}

This study, as mentioned in its title, deals with the internet of things as both a space or medium and an apparatus of public policies, specifically in the context of developing countries via the lens of comparative political analysis. To assess the internet of things ecosystem as an important component of the transformation process of the countries into the knowledge society from a perspective of developing countries which are differentiating primarily political, cultural and economic contexts, should be considered as a meaningful effort. In this sense, the present study debated the internet of things ecosystem and associates information technologies synchronically "opportunity" and "threats" realm for developing countries in the case of Turkey. At the end of the study, the present study would offer some recommendations for Turkey's newly established internet of things ecosystem governance.

Keywords: Internet of Things, Knowledge Society, Knowledge Capitalism, Information and Communication Technologies, Governmentality.

Geliş/Received: 20.01 .2020

Kabul/Accepted: 21.03 .2020

DOI: https://dx.doi.org/10.17336/igusbd.675949

* Doç. Dr., Hacettepe Üniversitesi, İletișim Fakültesi, Radyo, Televizyon ve Sinema Bölümü, Bilişim ve Enf. Teknolojileri ABD, Ankara, Türkiye, E-posta: ahmetserhat.kaymas@windowslive.com ORCID ID https://orcid.org/0000-0003-4096-1546 


\section{Giriş}

$\mathrm{Bu}$ çalışma, kamu politikalarının uzamı ve aracı olarak nesnelerin interneti (internet of things) ekosistemini, "karş̧laştırmalı siyasa analizi" perspektifinden değerlendirmeyi ve Türkiye'de sözü edilen ekosistemin yönetişimi için bir dizi öneri geliştirmeyi amaçlamıștır. Nesnelerin interneti ekosisteminin Türkiye'de bütüncül bir kamu politikasının odağında henüz yer alamaması bir yana, akademik ilgi içerisinde ancak sınırlı bir biçimde yer edinebilmesi (Göçoğlu, 2020; İban ve Aksu, 2020; Göygönür, Şensoy ve Mel, 2019; Ali ve Çalış, 2019, Yüksel, 2016) bu çalışma için önemli bir davetiye olarak değerlendirilmektedir. Bu doğrultuda çalışma, aşağıdaki iki soruya yanıt aramaktadır: (1) Nesnelerin interneti kavrayıșını, kamu politikalarının odağına yerleștiren bağlam nasıl kurulmuştur? Yanıtı aranan bu sorunun, özellikle Türkiye'de henüz sınırlarını ve yeni araștırma olanaklarını tartışabilmek için önemli bir işlevinin olduğu belirtilmelidir. Çalıșma ikinci sorusunda ise, Türkiye özelinde bir tartışma uzamı olușturmayı hedeflemektedir. Bu doğrultuda soru (2) Türkiye'nin bilgi toplumu dönüșüm süreçlerini destekleyebilen bir ulusal kamu politikası nasıl geliștirilebilir? Olarak belirlenmiştir. Türkiye'nin 56 milyon internet kullanıcısının yanı sıra Avrupa'nın toplam internet kullanıcılarının \%7.9'u gibi önemli bir oranını oluşturmasına (Internetworldstats; 2019:1), rağmen, nesnelerin interneti ekseninde yeni politikalara ihtiyaç duyması bu soruyu anlamlı kılmaktadır.

\section{Doğru \\ Çalışmanın Yöntemi, Sınırlılıkları ve Uzamı: Bir Kamu Politikası Önerisine}

$\mathrm{Bu}$ doğrultuda çalışma, nesnelerin interneti kavrayıșı ve art alanında yer alan internet ve bileșen teknolojiler ile "gerçek yaşam" arasında oluşan yeni bir ekosistemin kamu politikaları odağında sorgulanabilmesi için dört ana eksen belirlenmiștir. (1) Kamu politikalarının uzamı ve aracı olarak nesnelerin interneti kavrayışının, özellikle Türkiye için yeni bir yönetişim ve akademik çalıșma alanı olduğu dikkate alındığında, nesnelerin internetinin "ne" olduğu ve kamu politikaları için temsil ettiği değerler zinciri dönüşümü çalışmanın ilk tartışma eksenini oluşturmaktadır. (2) Çalışma, nesnelerin interneti politikalarını Avrupa Birliği, Amerika Birleşik Devletleri gibi alanın öncü politika merkezlerinin yanı sıra (Atkinson, 2014:4-5), Asya Pasifik ülkeleri gibi nesnelerin interneti kavrayışına egemen siyasaları içerisinde ilk kez yer veren ülke deneyimleri içerisinden de okumayı amaçlamıştır. Çalışmanın diğer iki tartışma alanında ise (3) Türkiye'de gelişmekte olan bir alan olarak uygulanan politikalar siyasa analizi yöntemi içerisinde ele alınmakta ve Türkiye'nin bilgi toplumu politikaları içerisinde nesnelerin interneti kavrayıșının nasıl bir değișim ve dönüșüm potansiyeline sahip olduğu tartışılmaktadır. Çalışmanın son tartışma uğrağını ise (4) Türkiye için alternatif politikaların nasıl geliştirilebileceğine dair öneriler oluşturmaktadır.

Çalışmanın yukarıda yer alan tartışma izleği doğrudan bir "karşılaştırmalı siyasa analizi" üzerinden bir tartışmanın gerçekleştirilmesini zorunlu kılmaktadır. Bununla birlikte, bu çalışma içerisinde böylesi bir analiz, kapitalizmin yakın dönemli uğrakları dikkate alınarak gerçekleștirilmektedir.

\section{Nesnelerin İnterneti ve Kamu Yönetişimi: Bir Soruyu Yeniden Ziyaret Etmek}

Nesnelerin interneti kavrayışı, 1999 yılında, Kenneth Ashton'un araştırma projesi içerisinde, en azından, isim olarak yer almasının ardından "internet" ve "gerçek dünya" bileşeni ortaya çıkarttığı yeni sorular ve sorun alanları ile birlikte hem kamu politikalarının hem alan yazının özel bir tartışma gündemini oluşturmuştur (Santucci; 
2010: 11-12). Bu yönü ile nesnelerin interneti kavrayıșını, en azından Türkiye için yeni olduğu da dikkate alındığında, belirginleştirmek ve ardından bu alt bölümün isminde yer aldığı üzere "bir soruyu" bu kez yeni bir bakış ile değerlendirmek önem taşımaktadır. Atzori, Iera ve Morabito (2010:1); kavramın art alanında yer alan temel düşüncenin, "insanın çevresinde yer alan nesnelerin ve objelerin belirli protokoller çerçevesinde tanımlanabilecek bir adrese sahip olması ile birbirleriyle etkileşim ve işbirliği içerisinde belirlenmiş temel görevleri yerine getirmesi" olduğunu belirtir. Ancak burada soru, yeni enformasyon ve iletişim teknolojileri aracılığı ile "gerçek" ve "sanal" dünyalar arasında kurulması amaçlanan ekosistemin, hem bir uzam hem de bir araç olarak kamu politikalarına nasıl bir davetiye gönderdiği ile ilişkilidir.

Nesnelerin interneti kavrayışının oluşturduğu geniş bağlam aslında henüz başından itibaren böylesi bir ekosistemin nasıl yönetilebileceğine dair anlamlı bir soruyu tam da kamu politikalarının odağına yerleștirir. Gerçekten de yeni ekosistem, geliștirdiği yeni uygulamalar aracılığı ile örnekleri ancak bilim kurgu filmlerinde görülebilen bir dizi köklü değișime yer verirken böylesi bir ekosistemin yönetişimi adına en azından bir endişenin de gelişmesine yol açmıştır. 0 denli ki, sürücüsüz otomobiller, kendi siparişini veren cihazlar, bakıma muhtaç ya da yaşlı yurttaşların bakım hizmetlerini ilgili kurumlarla paylaşan geniş ağ yapısı üzerinden kontrol etmesi, gittikçe karmaşıklaşan kent trafiğinin sürücüler için kesintisiz bir bilgi paylaşımı ile paylaşılması ve benzeri çok sayıda örnek birçok araştırmacı için "devrim" niteliğindedir. Akıllı makinelerden, "akıllı" şehirlerin inşasına, kapitalizmin yeni birikim koşulları içerisinde, örneğin endüstri 4.0 uygulamaları gibi, üretim ve birikim ilișkilerinin yeni uğraklarına son kertesinde ise yeni bir toplum yapısına işaret eden nesnelerin interneti kavrayıșı kamu politikaları için de yeni bir değerler dizisinin gelişmesi için bir davetiye göndermektedir. Ancak bu denli köklü bir değişiminin kamu yönetişimi için anlamının belirginleștirilmesi doğru olacaktır. Chatfield ve Reddick'in (2019:346) değerlendirdiği üzere, kamu yönetişimi içerisinde nesnelerin interneti "dijital yönetişim" perspektifinden gittikçe "akıllı yönetişim" kavrayışına doğru izlenen değerler dizisindeki değişim, yeni bir denklem oluşturacak denli ilerlemektedir.

Nesnelerin interneti ile birlikte denklemin bir ucunda, değişen kamu yönetişimi anlayışının, kamu hizmetlerinde, örneğin e-devlet uygulaması aracılığı gibi, yeni hizmet sunumları gibi (Göçoğlu; 2020:618) kamu ve yurttaş ilişkilerine yeni boyutlar eklemlediği açıktır. Ancak böylesi bir değișimin bir yandan da kamu yönetişiminin yeni değerler dizisi değişimi, bizatihi yönetişim kavrayıșının bilişsel kapitalizm dönemi ile birlikte yeniden değerlendirilmesi gereken boyutlarının olduğu belirtilmelidir. Örneğin kamu politikalarının değișen "değerler dizisinin"; Graham Murdock'ın (2017:31) ișaret ettiği üzere, toplumun geniş kesimleri içerisinde deneyimlenen enformasyon eşitsizliğinin bu kez yeni bir boyut olarak akıllı teknolojilere sahiplik eksenindeki eşitsizliklerle "başa çıkması" gereken yeni boyutları ile de tanışabileceği söylemi bu açıdan önem taşımaktadır. Riggi'nin (2013:404) ifadesi ile henüz "kapitalizm denizinin ancak küçük adalarını" oluşturan nesnelerin interneti kavrayışını kamu politikalarının ve yönetişim modellerinin odağına taşıyan bir dizi, üstelik oldukça güçlü, nedenler bulunmaktadır. Terry Flew ve Silvio Waisbord'un (2015:624-625) ortak çalışmalarında değerlendirdiği üzere, yeni enformasyon ve iletişim teknolojileri ile bileșen dijital ağların "melez bir medya ekosistemi" içerisinde biçimlenmesi kamu politikaları için de önemli bir değer dizisi değişimini olușturmaktadır. Flew ve Waisbord'a göre böylesi bir biçimlenme melez olmasından daha çok belirli medya teknolojilerinin önyargısını üretmektedir. Ancak bu tartışmayı; teknolojilerin ön yargısı olmaktan çok, yeni enformasyon ve iletişim teknolojileri yazınının, ağırlıklı olarak Amerika Birleşik Devletleri ve İngiltere öncelikli olmak üzere, gelişmiş ülkeler eksenindeki ihtiyaçlar ve önceliklerin "ön yargısı" olarak yeniden bir değer biçilmesi gerekir. Gerçekten de bu açıdan temel sorun, teknolojinin bir 
politika dönüşümünü içerecek denli kapitalizmin yeni birikim rejimlerinin nasıl kurulduğudur.

Gündelik yaşam ile yeni enformasyon teknolojilerinin oluşturduğu "ortak" kaynaklar üzerinden, kapitalizmin egemen üretim güçleri ve üretim ilişkileri diyalektiğine alternatif bir diyalektiğin geliștiği sıklıkla vurgulanır. Ancak böylesi bir vurgunun kamu yönetimini nasıl bir değerler değişimi ile çerçevelediği çok da açık değildir (Peters ve Reveley, 2015:6). İnternet ve bileşen teknolojilerin yönetişimi söz konusu olduğunda, kamu yönetişimi özelinde, aşağıda yer alan iki "güçlü" sorunun yanıtlanması gerekir. (1) nesnelerin interneti kavrayışı için önemli bir bağlam oluşturan "bilginin" mülkiyetinin ve bununla ilişkili olarak "fikri hakların" kamu politikalarının odağında nasıl yer edinebileceği? (2) ilk sorunun önemli bir tamamlayıcısı olarak internet ve bileşen teknolojilerinin; üstelik önceki dönemlerinde olmadığı denli "merkezsiz", "belirli bir ülkenin sınırlarına bağlı olmayan" ve "küresel" bir ağ içerisinde yapılanan alt yapısının ulusal kamu politikalarının odağında nasıl bir yönetişim modeline sahip olabileceği? Kamu yönetişimi için öncelikli sorun alanlarını oluşturmaktadır. Bu açıdan, bilgi toplumu söyleminin yerini gittikçe "internet sonrası toplum" söylemine bıraktığı yeni bir dönemin "şafağında", kamu yönetişim modellerinin de yeni bir değerler dizisi ile tanışması oldukça anlaşılabilirdir. Ancak böylesi bir anlaşılabilir olma halinin içeriği, egemen bir ikilimin yeniden ziyaret edilmesiyle doldurulabilir. İkilem; nesnelerin internetinin yükselişi ile birlikte demokrasi, eșitlik ve özgürlüğün egemen kılınacağı ortak kaynaklar üzerinden yeni bir üretim ilișkilerinin kurulacağı yönündeki bir "teknolojik ütopya" (Orsi, 2009:3133, Bauwens, 2009:121-125) karşısında yeni ekosistem içerisinde eșitsizliğin yeni biçimlerinin yükseldiği yönündeki düşüncede belirginleşir. Rifkin'e (2015:17) göre, ikilemin ilk ekseni, ekonomik paradigmalarda büyük bir dönüşümün ilk basamaklarında olduğumuzu müjdelemektedir. İkinci eksende ise; nesneler ve "gerçek" dünya arasında oluşan "yaratıcı ekosistemin", gerçekte, yeni bir gözetim toplumuna yol açarak bireysel özgürlükleri nerede ise yok edileceği bir karamsarlığı izlemektedir (Karatzogianni ve Michaelides, 2009:144-146, Kranenburg, 2010:26-28, Rifkin, 2015:121). Aralarındaki farklılıklara rağmen, her iki eksenin de gerçekte ilerleyen alt bölüm içerisinde yapıldığı üzere alternatif bir okumaya ihtiyaç duyduğu söylenmelidir. Nesnelerin interneti ile birlikte, yukarıdaki tartışmanın aslında, kapitalizmin nasıl yeniden ele alınabileceğinden bağımsız olmadığını söylemek gerekir. Richard Sennett'in (2017:143) işaret ettiği üzere kapitalizmin üretim, birikim ve bölüşüm ilişkilerinden kaynaklanan çelişki ve eşitsizliklerin giderilmesine dair saygın bir tarihçenin varlığı, "phalanstére, düşüncesinden bu yana açık bir biçimde bilinmektedir. Aslında, henüz on yedinci yüzyll gibi kapitalizmin erken bir tarihi değil tam aksine nesnelerin internetinin henüz öncesinde dahi kapitalizmin yeni bir deneyim arifesinin eşiğinde olduğu sıklıkla vurgulanmıștır.

\section{Nesnelerin İnterneti ve Gelişim Süreci: Alternatif Bir Okuma Denemesi}

Richard Stallman'ın 1984 yılında geliştirdiği "genel kamu lisansı” ile “özgür yazılım" (Riggi, 2013:399) projeleri bilgisayar yazılımlarının açık kodlar üzerinden toplumun geniş kesimleri arasında ücretsiz olarak kullanılmasını amaçlarken, bilişsel kapitalizm dönemine dair yukarıda işaret edildiği üzere, yeni alternatiflerin geliștirilmesi adına umut vermektedir. 0 denli ki, nesnelerin interneti kavrayışı öncesinde geliştirilen özgür yazılım ve genel kamu lisansı uygulamaları bu tarihten sonra da "neo liberal bilgi temelli toplumların" (Orsi, 2009:32) siyasa gündemlerinde özel bir yere sahip olmuştur. Ancak, nesnelerin interneti kavrayışı öncesine değin, ortak kaynakların kullanılması üzerinden kapitalizmin üretim, birikim ve bölüşüm rejimine alternatif oluşturma potansiyeline sahip üretim ilişkilerinin izlenmesine rağmen (Arvidsonn, 2013:22), 
hiçbirisinin küresel bir düzeyde ve alternatif ağlar oluşturarak piyasa yapısına alternatif geliștiremediği söylenmelidir.

Piyasa ilişkilerine alternatif olamasa da, kullanıcıları için sağlamış olduğu "özgürlükler"; nesnelerin interneti kavrayışının hemen öncesinde kamu yönetişim modellerini oldukça yakından ilgilendiren politika alanlarının oluşumuna katkı sunmaktadır. Bu doğrultuda yeni politika alanlarının ilk açısı, kapitalist birikimin o güne değin telif hakları, patentler ve fikri haklar üzerinden korumaya yöneldiği ticari sırları bu kez açık kodlar ve özgür yazılımlar üzerinden üstelik küresel bir düzeyde de yeniden biçimlendirmesidir. İkinci açı ise, içerisinde üzeri örtülü olarak da olsa, kapitalizmin önemli bir dönüşüm sürecinin tam da eșiğinde olduğunu belirginleştirmektedir. Ancak tam da buradaki sorun "bilişsel kapitalizmin" devletler ve yurttaşları için bir özgürlük alanı sunup sunamayacağı düşüncesinde belirginleşir (Fuchs, 205-208). Bununla birlikte, özgür yazılım, genel kamu lisansı ve açık kodlar uygulamalarının üzerinden geçen kısa süre içerisinde, nesnelerin interneti ekosisteminin ancak kamu politikaları ile bütünleşmesi gerektiğine dair önemli bir gündemin oluştuğu görülür. İnternet ve bileșen yeni enformasyon teknolojilerinin nesneler ve "gerçek dünya" arasında yaratıcı bir ekosistem oluşturarak ilerledikçe, Atzori, Iera ve Morabito'nun (2010:2) işaret ettiği üzere, kamu yönetişimi için gittikçe belirsizleșen bir alanın açıldığı görülür.

\section{Bilgi Teknolojileri ve Kamu Yönetişimi Diyalektiğini Okumak}

Nesnelerin interneti ile birlikte dijital yönetişim modellerinden akıllı yönetişim modellerine doğru yeni değerler dizisi ile karşılaşılması, Chatfield ve Reddick'in (2019:348) değerlendirdiği üzere gittikçe belirginliğini kaybeden kamu yönetişimi söylemini görünür kılmaktadır. Bu doğrultuda, nesnelerin interneti politikaları, toplumların siyasal, kültürel, sosyal ve ekonomik dönüşümleri ile bu dönüşümlerin refakatinde değişen kamu politikalarının kesitlerinde belirlenirken, söz konusu "belirginliğini kaybetme" söylemini tartışmak anlamlı olacaktır. Olabildiğince geniş söylendiğinde böylesi bir durum aslında kamu yönetişimi için yeni bir değerler dizisinin oluşumunu işaret etmektedir. Chatfield ve Reddick'i (2019:349) izleyerek nesnelerin internetinin, kamu yönetişimi için yeni bir yönetişim kuramına doğru ilerlediğini belirtmek bu doğrultuda önem taşımaktadır. Geniş bir bağlam içerisinden bakıldığında; kamu yönetiminin söz konusu değișimini, dijital teknoloji politikalarından kendi içerisinde yeni bir bağlamı işaret eden "akıllı yönetişim" politikalarına doğru bir geçiş süreci olarak değerlendirebilmek mümkündür.

Kamu politikaları için dönüşümün, yönetim için yeni bir sıfatı mı yoksa bir hileyi mi temsil ettiği (Anthopoulos, 2017:263) henüz tartışmalı olsa da, bilgi teknolojileri söz konusu olduğunda daha büyük ölçekteki sosyal, siyasal, ekonomik ve kültürel değişimin refakatinde kamu yönetişiminin de bir değişim içerisinde olması anlaşılabilir. Değiş̧im, aşağıdaki Tablo 1 içerisinde ana hatları ile tartışılmaktadır.

\footnotetext{
Akıllı Yönetişim Tanımları

Yönetimlerin toplumlardaki stratejik rolünün yanı sıra hükümetler arası koordinasyon, merkezsizleştirme, genişletilen katılım ve örgüt yapılarının yenilenmesi gibi etkililiği arttırılmış yönetişim kapasitesini geliştirmesidir Bütünleşik bilgi teknolojilerinin kullanılmasıyla, kentsel sorunları içeren hükümetlerin sorun çözme kapasitesinin artırılmasıdır.
}

\author{
Tanımların Vurguladığı Ana Temalar \\ Etkililiği arttırılmış kamu servislerinin \\ kurulması, hükümetlerin stratejik karar alma \\ süreçleri ile yönetişim kapasitesinin \\ geliştirilmesi. \\ Bütünleşmiş bilgi teknolojilerinin \\ kullanılması ile hükümetlerin sorun çözme \\ kapasitesinin genişletilmesi.
}


Akıllı Yönetişim Tanımları

Enformasyon teknolojileri kapasitesinin geliştirilmesi ve iş süreçlerinin uygulanması ile enformasyonun, hükümet organları arasında sorunsuz akışının sağlanmasıdır.

Enformasyon teknolojilerinin genişletilmiş kullanılması ile açık veri ile büyük verinin etkin kullanılmasıdır.

Yönetimlerin farklı birimleri arasında güçlenen işbirliği aracılığı ile açık bir yönetimin gerçekleştirilmesidir. Sürecin önemli bir unsuru, böylesi bir işbirliği ile bilgi güvenliği ve dijital şehirler gibi yeni yönetişim modellerinin uygulanabileceği uzamların açılmasıdır.

Açıklık ve istikrarlı karar verme, enformasyonun açık bir biçimde paylaşımı ve kullanılması, taraflar arasında işbirliği ve katılımın geliştirilmesi ile yönetim uygulamalarının ve kamu hizmeti servislerinin güçlendirilmesidir. Bilişim teknolojilerinin yeniliklerin kolaylaştırılması, sürdürülebilirliğin sağlanması, rekabet ve yaşamsallık gibi unsurların güçlendirilmesi amacıyla kullanıldığı yönetim biçimidir.

Bilişim teknolojilerinin genişleyen kullanımı aracılığı ile enformasyonun yönetim birimleri içerisinde sorunsuz akışını sağlamak bu yönüyle de yüksek nitelikli yurttaş servislerinin ve yönetim programlarının tüm alanlarda gelişmesini amaçlamaktır.

Bilgi teknolojileri, iletişim ve operasyonel teknolojilerin yönetim hizmetlerinin planlanması ve yönetişim modeline aktarılması ile farklı uzamlarda, işlem süreçlerinde ve yargıda sürdürülebilir kamu değerinin oluşturulmasıdır.

Bilgi teknolojileri aracılığı ile geleneksel edevlet hizmetlerinin genişletilmesi ve nesnelerin interneti aracılığı ile internet temelli yeni devlet hizmetlerinin bütünleşmesinin sağlanmasıdır.
Tanımların Vurguladığı Ana Temalar

Yönetim organları arasında enformasyon erişiminin ve ağ paylaşımının güçlendirilmesi ile yönetim kapasitesinin geliştirilmesi.

Enformasyon teknolojilerinin kullanımının geliştirilmesi ile kapasitenin arttırılması.

Yönetim birimleri arasındaki ișbirliğinin geliștirilmesi ile yeni bir yönetişim yaklaşımının geliştirilmesi.

\section{Akıllı teknolojilerin kullanılması ile yeni} bir ekosistemin kurulması

Enformasyonun yönetim birimleri ve programları içerisinde sorunsuz akışını sağlamak ve yurttaş hizmetlerinin niteliğinin artması.

Bütünleşmiş bilgi teknolojilerinin oluşturulması ile farklı alan ve uzamlarda kamu değerinin oluşturulması ve sürdürülebilirliğinin sağlanması.

Devlet uygulamalarının açık ve şeffaf bir biçimde nesnelerin interneti alanına genişletilerek aktarılmasıdır.

Tablo 1: Akıllı Yönetişim Alanları ve Temaları (Chatfield ve Reddick (2019:5).

Tablo 1'in ayrıntılı olarak değerlendirilmesi ile görülebileceği üzere, yukarıda yer alan tanımların kamu hizmetleri için, "akıllı yönetişim", olmak üzere yeni bir yönetişim biçimini ve yeni bir değerler dizisini tanımlarken, gerçekte, bilgi teknolojilerinin kamu hizmetlerindeki genişleyen kullanımını vurguladığı görülür. Ancak, bilgi teknolojilerini ulusal kaynakları ile geliştiremeyen ülkeler perspektifinden bakıldığında sözü edilen "dijitalleşmenin" yeni bir bağımlılığa, teknolojik bağımlılığa, yol açabileceği yönündeki olası bir sonuç, en azından bu çalışmanın yazarı için, "kaygı" uyandırmaktadır (Castelnovo, Misuraca, Savoldelli; 2015, Kong ve Wood; 2018). Örneğin Kong ve Wood'un 
(2018:682) çalıșmalarının isminde de yer aldığı üzere, akılcı yönetişim söylemi ideolojik bir yanılsama olarak değerlendirilmektedir.

Gelişmiş ülkelerden farklı olarak, araştırma geliştirme faaliyetleri ile teknolojik altyapılarını kendi olanakları ile geliştirmekte sorunlarla karşılaşan gelişmekte olan ülkeler için söz konusu "akılcı yönetişım" kavrayışının önemli bir dizi soruna yol açabileceği potansiyel bir "tehdit" olarak dikkat çekmektedir. Bu nedenle, akıllı yönetişim kavramı ile kamu yönetişimi alanındaki değişim sürecini tartışmak anlamlı olacaktır.

\begin{tabular}{|c|c|c|c|c|}
\hline & $\begin{array}{c}\text { Enformasyon } \\
\text { Erișilebilirliği } \\
\end{array}$ & $\begin{array}{c}\text { Anlamlı } \\
\text { Enformasyon }\end{array}$ & Amaçlanan Eylem & Akıllı Yönetişim \\
\hline $\begin{array}{c}\text { Yurttaş } \\
\text { Katılımı }\end{array}$ & $\begin{array}{c}\text { Yönetişim } \\
\text { Monoloğu: } \\
\text { Enformasyon ve } \\
\text { kamu } \\
\text { hizmetlerinin } \\
\text { dijitalleşmesi ile } \\
\text { internet ve } \\
\text { telefon gibi farklı } \\
\text { dağıtım kanalları } \\
\text { üzerinden } \\
\text { dağıtılması. Bu } \\
\text { noktada } \\
\text { enformasyonun } \\
\text { iyi örgütlenmesi } \\
\text { gerekmemektedir. }\end{array}$ & $\begin{array}{l}\text { Yaygın Yönetişim } \\
\text { Monoloğu: } \\
\text { Sosyal medya veya } \\
\text { radyo frekansları } \\
\text { gibi araçların } \\
\text { belirlenmesi } \\
\text { üzerinden dijital } \\
\text { kamu } \\
\text { enformasyonun } \\
\text { dağlabileceği yeni } \\
\text { araçların } \\
\text { belirlenmesi }\end{array}$ & $\begin{array}{l}\text { Yönetişim } \\
\text { Diyaloğu: } \\
\text { Akıllı telefonlar } \\
\text { gibi gerçek } \\
\text { zamanlı } \\
\text { enformasyon } \\
\text { paylaşımı }\end{array}$ & $\begin{array}{c}\text { Yurttaş Yönetişim } \\
\text { Diyaloğu: } \\
\text { Karar alım süreçlerinde } \\
\text { yurttaşın artan ağırlığı } \\
\text { ile yönetim ve yurttaş } \\
\text { arasındaki diyaloğun } \\
\text { gelişmesi }\end{array}$ \\
\hline $\begin{array}{c}\text { Enformasyon } \\
\text { Şeffaflığı }\end{array}$ & $\begin{array}{c}\text { Açık Veri: } \\
\text { Veri tabanlarının } \\
\text { ve kamusal } \\
\text { erişime açık } \\
\text { veriler için ilgili } \\
\text { politikaların } \\
\text { belirlenmesi }\end{array}$ & $\begin{array}{c}\text { Anlamlı Veri: } \\
\text { Yüksek değerli veri } \\
\text { tanımı, verilerin } \\
\text { gelişime açı } \\
\text { olarak kullanılması }\end{array}$ & $\begin{array}{l}\text { Her zaman, Her } \\
\text { Yerde Veri: } \\
\text { Çeşitli platformlar } \\
\text { aracılığı ile veri } \\
\text { kullanılabilirliğinin } \\
\text { düzenlenmesi }\end{array}$ & $\begin{array}{l}\text { Kişiselleşmiş } \\
\text { Enformasyon } \\
\text { Yurttaşı "profiline" } \\
\text { göre, kamusal } \\
\text { enformasyonun } \\
\text { yurttaşa doğrudan } \\
\text { gönderilmesi }\end{array}$ \\
\hline $\begin{array}{c}\text { Hizmet } \\
\text { Dağılımı için } \\
\text { İşbirliği }\end{array}$ & $\begin{array}{c}\text { Online } \\
\text { Enformasyon: } \\
\text { Kamuya } \\
\text { sunulacak } \\
\text { enformasyona } \\
\text { çevrimiçi erişimin } \\
\text { sağlanması }\end{array}$ & $\begin{array}{c}\text { Sinırlı Online } \\
\text { İşbirliği: } \\
\text { Yönetişim } \\
\text { unsurları arasında } \\
\text { veri paylaşımı ve } \\
\text { kamu içeriklerinin } \\
\text { belirlenmesi }\end{array}$ & $\begin{array}{c}\text { Birimler } \\
\text { Arasındaki } \\
\text { İşbirliği: } \\
\text { Kamu içeriklerinin } \\
\text { birimler } \\
\text { arasındaki işbirliği } \\
\text { eliyle paylaşılması }\end{array}$ & $\begin{array}{c}60 \text { Derece Yurttaş } \\
\text { Servisleri } \\
\text { Anlık değişim ve } \\
\text { ihtiyaçlara göre, } \\
\text { yurttaşın ihtiyaç } \\
\text { duyduğu } \\
\text { enformasyonun } \\
\text { hazırlanması ve erişime } \\
\text { açılk tutulması } \\
\end{array}$ \\
\hline & Sahne 1 & Sahne 2 & Sahne 3 & Sahne 4 \\
\hline
\end{tabular}

Tablo 2: Akıllı Yönetișim ve Yönetişimin Değișen Boyutları (Anthopoulos (2017).

Tablo 2 içerisinde yer aldığı üzere, kamu politikalarının yeni, "akıllı", dönemi bilgi teknolojilerinin gündelik yaşam pratiklerinde edindiği yere koşut olarak yurttaş ve yönetim arasındaki ilişkilerin de yine söz konusu teknolojinin dolayımı eliyle kurulan bir etkileşime dönüştürmüștür. Akıllı yönetişim söylemi, alan yazın içerisinden bakıldığında, her ne kadar ağırlıklı olarak şehir yönetimlerindeki değişim üzerine gelişmişse de nesnelerin interneti gibi sanal bir uzamı, interneti, gerçek nesneler ile eklemleyen yeni bir ekosistem içerisinde de genişleyen bir dizi tartışmanın odağında yer almaktadır. Bilgi teknolojilerinin, kamu politikalarını nesnelerin interneti içerisinden okumaya "niyetlenen" bu çalışmanın amacı doğrultusunda sözü edilen söylemin egemen siyasa içerisinde nasıl kurulduğunu tartışmak anlamlıdır. Bir sonraki alt bölüm içerisinde, karşılaştırmalı bir siyasa analizi üzerinden egemen siyasa içerisinde nesnelerin interneti 
kavrayışının nasıl kurulduğu bu doğrultuda da "akıllı yönetişim" söyleminin yeni ekosistem içerisinde nasıl sürdürüldüğü tartışılacaktır. Bu doğrultuda çalıșmanın ilerleyen bölümleri içerisinde "egemen siyasa tasarımında nesnelerin interneti" ülke deneyimleri ekseninde ele alınıp tartışılmaktadır.

\section{Avrupa Birliği Siyasası İçerisinde Nesnelerin İnterneti Yönetişimi}

Avrupa Birliği içerisinde nesnelerin interneti politikalarını, bakanlıklar arasındaki ilk toplantının gerçekleștirildiği 2008 ya da nesnelerin interneti üzerine Avrupa için Hareket Planı bildiriminin hazırlandığı 2009 yılından itibaren ele almak kabul edilebilir (Yüksel, 2016:124-125; http://www.ec.europe.eu, 2019; http://www.ec.europe.eu, 2016). Ancak, AB için bütüncül ve sürdürülebilir politikaların gerçekleşmeye başladığı 2015 yılı Mart ayında itibaren başlayan bir tarihçenin oluşturulması bu açıdan daha doğru olacaktır. Avrupa Birliği içerisinde bir bakıma ilerleyen yıllarda yeni bir "düzenleyici otorite" olarak yapılandırılacak olan "Nesnelerin İnterneti Yenilikleri İttifakı'nın" kurulmasıdır. Kurulduğu ilk gününden itibaren Avrupa Komisyonu tarafından desteklenen söz konusu İttifakın, 30 Mayıs 2016'da İttifak Yönergesinin belirlendiği "Üçüncü Genel Toplantısı'nda" İttifakın yasal bir temel çerçevesinde Avrupa Birliği içerisinde düzenleyici bir otorite olarak geliştirilmesine karar verilmiştir.

Karar, 22 Eylül 2016 tarihinde, İttifakın bağımsız bir yapıya dönüştürülmesi ile sonuçlanmıştır. Bu tarihin ardından ise İttifakın, nesnelerin interneti teknolojisi alanında Avrupa'nın "en büyük" platformu olarak özel sektör, üniversiteler ve kamu ile ortaklaşa araştırma ve geliştirme projelerini geliştirdiği görülmektedir. Bu doğrultuda nesnelerin interneti teknolojilerinin 2014 yılı gerçekleșen ticari büyüklük üzerinden ele alınması ile AB'nin 2020 yılındaki ticarete dair potansiyel öngörülerinin, bir fikir oluşturabilmesi için, ele alınması anlamlı olacaktır. Aşağıdaki Tablo 3 içerisinde Avrupa Komisyonu tarafından gerçekleștirilen çalıșma bu doğrultuda yer almaktadır. Bununla birlikte, Tablo 3'ün sunulmasının öncesinde genel bir değerlendirme yapılmalıdır.

Avrupa Komisyonu'nun (http://www.ec.europe.eu, 2016:31) nesnelerin interneti çalışmasına göre; Avrupa Birliği üyelerinin tümü sözü edilen yeni ekosistemden etkilenecek olmasına rağmen, halen İngiltere, Almanya ve Fransa nesnelerin interneti teknolojilerinde $A B$ 'nin toplam gelirlerinin yarısını elde etmiştir. $\mathrm{Bu}$ doğrultuda, $\mathrm{AB}$ içerisinde önemli bir gelir eşitsizliğinin olduğu dikkati çekmekte iken, yukarıda sözü edilen ülkelerin yanı sıra İspanya, İtalya ve Hollanda olmak üzere 6 ülke, AB gelirlerinin \%75'ini elde etmiştir. Avrupa Birliği içerisinde nesnelerin interneti teknolojisinde elde edilen gelir düzeyine göre ilk 9 ülke ve Birliğin genel toplamı Tablo 3 içerisinde yer almaktadır.

\begin{tabular}{|c|c|c|}
\hline Üye Ülke & 2014 Yılı (gerçekleşen-milyon Euro) & 2020 Yılı (öngörülen-milyon Euro) \\
\hline Belçika & 9.353 & 28.328 \\
\hline Almanya & $\mathbf{7 1 . 1 1 4}$ & $\mathbf{2 4 3 . 6 4 2}$ \\
\hline İspanya & 24.500 & 65.570 \\
\hline Fransa & $\mathbf{5 5 . 4 4 4}$ & $\mathbf{1 8 5 . 0 8 6}$ \\
\hline İtalya & 32.087 & 97.927 \\
\hline Hollanda & $\mathbf{1 8 . 5 8 4}$ & $\mathbf{5 7 . 9 2 2}$ \\
\hline Polonya & 9.017 & 26.494 \\
\hline İsveç & $\mathbf{1 3 . 4 3 6}$ & $\mathbf{5 0 . 1 9 9}$ \\
\hline İngiltere & 78.678 & 269.283 \\
\hline $\begin{array}{c}\text { Diğer Ülkeler } \\
\text { Geneli }\end{array}$ & $\mathbf{5 3 . 7 7 8}$ & $\mathbf{1 5 7 . 1 5 2}$ \\
\hline Toplam & $\mathbf{3 6 5 . 9 9 2}$ & $\mathbf{1 . 1 8 1 . 6 0 3}$ \\
\hline
\end{tabular}

Tablo 3: AB İçerisinde Nesnelerin İnterneti Pazar Büyüklüğü ve Gelecek Tahmini (http://www.ec.europe.eu, 2016:31). 
Nesnelerin interneti teknolojisinin Avrupa Birliği içerisinde önemli bir pazar büyüklüğüne ulaşması, yukarıda da değinildiği üzere, Birliğin "tek pazar" politikalarını bu kez bilgi teknolojileri alanına doğru genişleterek "dijital tek pazar" politikalarını uygulaması için önemli bir gerekçe oluşturmuştur. Avrupa Birliği için nesnelerin interneti teknolojileri alanında 2014 yılında gerçekleșen 366 milyar Euro düzeyindeki mali büyüklügün yanı sıra 2020 yılında 50 milyarın üzerindeki cihazın nesnelerin interneti ekosistemi içerisinde yer alarak 1 trilyon Euro düzeyine ulaşlacağı öngörülen mali büyüklüğün de önemli bir gerekçe sunduğu tartışllmaktadır (Maple, 2017:156).

Avrupa Birliği, bu doğrultuda, 2015 Mayıs ayında yukarıda da yer aldığı üzere tek pazar politikalarını bu kez bilgi teknolojileri ve nesnelerin interneti ekosistemine genișleterek "dijital tek pazar stratejisi" programını uygulamaya başlamıștır (http://www.ec.europe.eu, 2019). Program, öngörülebileceği üzere, Avrupa'nın gerek iș çevreleri ile Avrupa Endüstrisi ve gerekse toplumun gündelik yaşam pratiklerindeki dijital dönüşümünü (digitising Europe) hedeflemektedir.

Avrupa Birliği, böylesi bir dönüşümün yol haritasını 19 Nisan 2016'da "Avrupa Endüstrisinin Dijital Dönüşümü Raporu'nun" bir parçası olarak, "Avrupa'da Nesnelerin İnternetinin Geliştirilmesi" çalışma raporu içerisinde üç ana sütun üzerinden belirlemiştir. Çalışma Raporu içerisinde yer aldığı üzere söz konusu sütunlar aşağıdaki Tablo 4 içerisinde ele alınmaktadır.

\begin{tabular}{|l|l|}
\hline Strateji & Açılama \\
\hline $\begin{array}{l}\text { Nesnelerin Interneti için Tek } \\
\text { Pazar Uygulaması }\end{array}$ & $\begin{array}{l}\text { Nesnelerin internetinin gelişebilmesi için AB sınırları } \\
\text { içerisinde ve ötesinde nesnelerin interneti teknolojisinin } \\
\text { sorunsuz çalıșabilmesi için önemlerin alınması. }\end{array}$ \\
\hline $\begin{array}{l}\text { Nesnelerin Interneti } \\
\text { Ekosisteminin }\end{array}$ & $\begin{array}{l}\text { Açık platformlar ve ortak kaynakların geliştirilmesi, başlangıç } \\
\text { olarak nesnelerin interneti teknolojisinin yaygın olarak }\end{array}$ \\
Yaygınlaştırılması & kullanıldı̆̆ pazarlarda bu teknolojinin desteklenmesi. \\
\hline Nesnelerin İnterneti & Nesnelerin interneti teknolojisinin, Avrupa değerlerine saygllı \\
Ekosistemi içerisinde İnsan & olarak gelişmesi, insanı merkeze alarak söz konusu \\
Merkezli Yaklaşımın & teknolojinin kullanılması, yüksek standartların uygulanması ile \\
Geliştirilmesi & veri güvenliğinin sağlanması ile bireylerin korunması, \\
& "güvenilir nesnelerin interneti" yaklașımının geliștirilmesi \\
\hline
\end{tabular}

Tablo 4: Avrupa Komisyonu Çalışmasında Nesnelerin İnterneti Stratejileri (http://www.ec.europe.eu, 2016:4-5).

Avrupa Birliği'nin nesnelerin interneti yönetişimi için bir dizi alanda politika ve stratejilerini belirlemesinin yanı sıra sözü edilen ekosistem içerisinde bir dizi keskin sorunla da karşılaştığı belirtilmelidir. Bu doğrultuda, Constance'ın (2017:153) öne sürdüğü üzere, sözü edilen ekosistem içerisinde veri güvenliğinin sağlanması Avrupa Birliği politikalarının karşısında önemli bir sorun olarak öne çıkmaktadır. Avrupa Birliği'nin nesnelerin interneti politikalarını Mayıs 2018'den itibaren, özellikle ticari kesimler tarafından "keskin" olmakla eleștirilen, yasal düzenleme ile "desteklediğini" belirtmek gerekir. Yürürlüğe 25 Mayıs 2018 tarihinde giren "Avrupa Birliği Genel Veri Koruma Düzenlemesi" (http://www.ec.europe.eu, 2018; http://www.eugpdr.org, 2019), AB yurttaşları ile Avrupa "ekonomik uzamı" içerisinde bireyler ve şirketler için veri koruma ve gizliliğine ilişkin olarak geliştirilmiştir. Bununla birlikte söz konusu Düzenlemenin, $\mathrm{AB}$ yurttaşlarının ve şirketlerinin veri güvenirliğinin sağlanmasının yanı sıra, Türkiye'nin üyelik müzakereleri de dikkate alındığında, üç önemli amacının daha vurgulanması gerekir. AB'nin söz konusu Yönerge üzerinden; (1) Avrupa Birliği genelinde veri güvenirliği yasalarının uyumlaştırılması, (2) Avrupa Birliği yurttaşlarının kişisel verilerinin korunması ve kişisel güvenliğin güçlendirilmesi ile son olarak (3) Avrupa 
genelinde Örgütler arası veri güvenirliği yaklaşımlarının uyumlaştırılması ve yeniden biçimlendirilmesi amaçlanmıştır (http://www.eu.gdpr.org, 2019).

Avrupa Birliği'nin yukarıda yer alan amaçlar doğrultusunda hem oldukça ayrıntılı olarak hazırlanan hem de 25 Mayıs 2020 tarihinden itibaren Avrupa Komisyonu'nun her dört yılda bir güncelleme yapacağı dikkate alındığında düzenli olarak güncellenen bir Yönerge oluşturduğu söylenmelidir (http://www.eur-lex.europe.eu, 2018). Bununla birlikte, yukarıda söz edildiği üzere, Avrupa Birliği ile uzun süren "üyelik müzakereleri" dikkate alındığında, Yönergenin Türkiye'yi önemli ölçüde etkileyebilme potansiyeli bulunmaktadır. Bu doğrultuda, 6698 Sayılı "Kişisel Verilerin Korunması Kanunu" (http://www.resmigazete.gov.tr, 2016) Türkiye ve Avrupa Birliği ilişkilerindeki kanunların "uyumlaşması" süreci için özel bir örneği temsil etmektedir.

Avrupa Birliği içerisinde, nesnelerin interneti politikalarını düşünme yollarından birisi de üye devletlerin politikalarının ele alınmasına doğru açlır. Birlik üye ülkeleri, Birliğin genel siyasasına uyumlu olmakla birlikte bilgi toplumu dönüşümleri çerçevesinde ayırt edilebilen bir dizi politikayı 2000'li yıllardan bu yana uygulamaya koymuşlardır. Öngörülebileceği üzere, Avrupa Komisyonu'nun (2016:34) Çalışma Raporu'nda da yer aldığı gibi, nesnelerin interneti teknolojilerinde, diğer üye ülkelere göre daha önde olan ülkelerin politika uygulamalarının da daha önde olduğu görülmektedir. Avrupa Komisyonu'nu Birlik üyelerini nesnelerin interneti girişimlerini kullanma kapasiteleri esasında "lider" ve "takipçi" olmak üzere iki ana kategori ekseninde sınıflandırdığı belirtilmelidir. Tablo 5 içerisinde, üye ülkelerin sözü edilen ayrıma göre dağılımı yer almaktadır.

\begin{tabular}{|l|l|l|l|}
\hline $\begin{array}{l}\text { AB Üye Ülkelerinde } \\
\text { Nesnelerin İnterneti } \\
\text { Politikaları }\end{array}$ & \multicolumn{2}{|c|}{\begin{tabular}{l} 
Üye Devletlerin Nesnelerin Interneti Kapasiteleri \\
\cline { 2 - 3 }
\end{tabular}} & \multicolumn{2}{|c|}{ Takipçiler } \\
\hline \multirow{2}{*}{ Giriş̧imler } & Liderler & $\begin{array}{l}\text { Finlandiya, Fransa, Ispanya, } \\
\text { Portekiz }\end{array}$ & $\begin{array}{l}\text { Almanya, Hollanda İsveç, } \\
\text { İngiltere }\end{array}$ \\
\cline { 2 - 4 } & Takipçiler & $\begin{array}{l}\text { Bulgaristan, Hırvatistan, Kıbrıs } \\
\text { Rum Kesim, Çek Cumburiyeti, } \\
\text { Yunanistan, Macaristan, İrlanda, } \\
\text { Letonya, Malta, Litvanya, } \\
\text { Romanya, Slovakya, Slovenya }\end{array}$ & $\begin{array}{l}\text { Avusturya, Belçika, } \\
\text { Danimarka, İtalya, } \\
\text { Lüksemburg, Polonya }\end{array}$ \\
\hline
\end{tabular}

Tablo 5: Avrupa Birliği Üye Ülkelerinde Nesnelerin İnterneti (http://www.ec.europe.eu, (2016:34).

Tablo 5 değerlendirildiğinde, Avrupa Birliği içerisinde önemli bir ayrımın vurgulanması gerekmektedir. Birlik içerisindeki göreli olarak "daha güçlü" olan Almanya, İsveç, İngiltere ve Hollanda'nın nesnelerin interneti ekosistemi içerisinde de daha güçlü bir yapıya sahip olduğu görülmektedir. Ancak Avrupa'nın "gelişmekte olan" ya da farklı bir biçimde ifade edildiğinde Birliğin "küçük" ya da "orta ölçekli" ülkelerinin (http://www.ec.europe.eu, 2016:34) nesnelerin interneti ekosisteminde oldukça az sayıda Yönergeye sahip olduğu belirtilmelidir (http://www.ab.gov.tr, 2019). Örneğin, İngiltere'nin nesnelerin interneti ekosistemi içerisinde yukarıda sözü edildiği üzere "lider" bir ülke olmasının yanı sıra Avrupa Birliği içerisinde de nesnelerin interneti teknolojilerinde en fazla yönerge geliştiren ülke olduğu söylenmelidir. İngiltere "Ulusal Hükümetin" desteklerinin yanı sıra Ulusal Hükümetin bir organı olarak yer alan "Teknoloji Stratejileri Platformu" tarafından geliştirilen yönergelere sahiptir. Bu doğrultuda özellikle "Nesnelerin İnterneti Yakınsama" programının özel bir önemi bulunmaktadır. Avrupa Birliği'nin diğer ülkelerinde ise nesnelerin interneti teknolojileri 
politikalarının yine ya Ulusal Hükümetler ya da Bakanlıklar eliyle geliştirildiği söylenmelidir. Örneğin; Almanya "Federal Hükümet Ekonomi ve Teknoloji Bakanlığı", Hollanda "Altyapı ve Çevre Bakanlığı", İrlanda "Ulusal Hükümet Endüstriyel Gelişim Bakanlığı" eliyle nesnelerin interneti politikalarını sürdürmektedir. AB'nin diğer ülkeleri ise Ulusal Hükümetlerinin yanı sıra örneğin Yunanistan, İspanya ve Polonya'da görüldüğü üzere yerel yönetimleri ya da belediyeleri üzerinden nesnelerin interneti politikalarını geliştirmektedir (http://ec.europe.eu, 2016:34-38).

\section{Amerika Birleşik Devletleri ve Nesnelerin İnterneti Politikaları}

Amerika Birleșik Devletleri'nin, internet ve bileșen yeni enformasyon bilgi teknolojilerinin keșfedilme ve geliștirilme süreçlerinde küresel düzeyde önemli bir konumu bulunmasına rağmen, nesnelerin interneti ekosistemi yönetişimi açısından Avrupa Birliği'nin ardında yer alması bir dizi eleștiriye yol açmıştır. Chatfield ve Reddick (2019:350); Amerika Birleşik Devletleri'nin, özellikle siber güvenlik alanındaki politikalarda Avrupa Birliği'nin ardında kalmasını; ABD'nin nesnelerin interneti teknolojilerini, internet ve bileşen bilgi işlem teknolojilerinin oluşturduğu ağlara göre bir dizi farklılık içermesi nedeniyle bağımsız bir kamu yönetişim modeli oluşturamamasından kaynaklandığını belirtir. İnternet ve nesneler arasında kurulan bağın niteliği ile internet ve bilgi teknolojileri arasındaki bağın oluşturduğu ekosistem arasındaki temel farklılıklar Amerika Birleșik Devletleri'nin ayırt edici bir kamu yönetişim modeli oluşturmasını engellemektedir. Teknolojik alt yapı farklılıklarının yanı sıra, Amerika Birleşik Devletleri'nin kendi içerisinde tutarlı ve bütüncül kamu politikalarını uygulamasının önündeki diğer engellerin de vurgulanması gerekir.

Amerika Birleşik Devletleri'nin nesnelerin interneti ekosistemi içerisinde karşı karşıya kaldığı "çelişkilerin", Birleşik Devletler hükümetleri için ortaya çıkan bir diğer boyutunu yeni ekosistemin "desteklenmesi" ile "güvenliğin sağlanması" arasında bir denge politikasının gözetilmesine yol açtığı belirtilmelidir (Chatfield ve Reddick, 2019: 350, Mapple, 2018:168-169). Nesnelerin interneti teknolojileri söz konusu olduğunda, Amerika Birleşik Devletleri'nin “devlet güvenliği” söyleminin oldukça ağırlık kazandığı söylenebilir. Bu doğrultuda, Amerika Birleşik Devletleri araştırmacıları tarafından, askeri personelin giyilebilir teknolojiler aracılığı ile internet üzerinden yerlerinin tespit edilebildiğini belirlemesinin ardından Savunma Bakanlığı'nın, askeri personel için coğrafi konumlarını belirleyen giyilebilir teknolojilerin kullanılmasını yasaklaması nesnelerin interneti ekosistemine ilişkin güvensizliğini ortaya çlkartan anlamlı bir örnektir (Sherman, 2018:1). Öte yandan Weber'in (2018:241) değerlendirdiği üzere, ABD politikaları, Obama'nın başkanlığı dönemi ile birlikte, Rusya, İran ve Çin Halk Cumhuriyeti ve Kuzey Kore öncelikli olmak üzere bir devlet güvenliği politikası olarak inşa edilmektedir. Ancak, Amerika Birleşik Devletleri'nin bir diğer önceliğinin daha olduğu vurgulanmalıdır. Serbest pazar politikalarının küresel mimarı olarak Amerika Birleşik Devletleri'nin nesnelerin interneti ekosistemi içinde de yine sözü edilen küresel şirketlerin etkisinde kaldığı görülmektedir. Bu doğrultuda, Amerika Birleşik Devletleri ve şirketlerin etkileşimine dair oldukça anlamlı bir örneğin verilmesi doğru olacaktır. Bilgi teknolojileri ve yazılım alanında çok uluslu küresel etkinliğe sahip bir şirket olan Intel'in (2019:3) henüz 2019 yılı başında nesnelerin interneti ekosistemi için "kamu politikaları çerçevesi" belirlemesi ve Amerika Birleşik Devletleri hükümetini sözü edilen yeni ekosistem içerisinde kamu politikalarını özel sektör ile geliştirmek için davet etmesi dikkat çekmektedir. Özel bir şirketin hükümeti politika geliştirmek için teşvik etme yönündeki "çabasını" ironiye dönüştüren ise, Birleşmiş Milletlere bağlı bir kuruluş olan Uluslararası Telekomünikasyon Birliği'nin (ITU), nesnelerin interneti ekosistemi içerisinde ulus devletlerin politika üretme gücünü gittikçe kaybettiğini ifade etmesi 
oluşturur. ITU, hükümetlere ancak bir dizi "tavsiye" kararını benimsemeleri önerisi getirmiștir (ITU, 2018:4, Puppis, 2008; Picard, 2007).

Amerika Birleşik Devletleri'nin, nesnelerin interneti teknolojilerine dair politikalarını üç önemli eksende belirlemiștir. Buna göre a) küresel rekabet nedeni ile bilgi teknolojileri alanında özellikle Avrupa Birliği'nin ardında kalmamak, b) yeni bir bilimsel alanın kurulmasını destelemek ve son olarak c) siber uzamda ulusal güvenlik stratejilerinin bir uğrağı olarak nesnelerin interneti siyasasını oluşturmak (Weber, 2018: 251-252) Amerika Birleşik Devletleri'nin önemli siyasa hedeflerini oluşturmaktadır. Amerika Birleşik Devletleri, yeni ekosistem içerisinde politikalarını yukarıda da belirtildiği üzere kamu ve özel sektör arasındaki işbirliği çerçevesinde geliștirmektedir. Mayıs 2016 yılında Birleşik Devletlerin nesnelerin interneti ekosistemi içerisindeki ilk siyasa belgesinden itibaren (NIST, 2016) sözü edilen ișbirliğinin gelișerek sürdüğü belirtilmelidir. Bu doğrultuda, Birleșik Devletlerin siyasasına temel oluşturan ilk Rapor içerisinde nesnelerin interneti ekosisteminin ilerleyen yıllarında oldukça geniş bir uzama yayılacağı belirtilerek kamu kuruluşlarının olduğu kadar ilgili sektörlerden de geniş katılımlı bir platformun kurulmasının teklif edildiği (Grefor, Greer, Wollman ve Burns; 2017:38) görülmektedir. Birleşik Devletler için özellikle ulusal güvenliğin sağlanabilmesi için 2017 yılında "Nesnelerin İnterneti Gelişim Yasası"1 yürürlüğe girmiştir. Bununla birlikte, Amerika Birleşik Devletleri'nin henüz Avrupa Birliği'nce gerçekleştirildiği gibi, yukarıda yer verilen "Avrupa Birliği Genel Veri Koruma Düzenlemesi” gibi kapsamlı bir yasal düzenlemeye henüz sahip olmadığı belirtilmelidir.

\section{Türkiye ve Gelişmekte Olan Ülkelerde Nesnelerin İnterneti Politikaları}

Nesnelerin interneti ekosistemi için bütüncül bir kamu yönetişim modeline sahip olmamakla birlikte, Türkiye'nin yalnızca 2013-2018 olmak üzere beş yıllık dönemi içerisindeki söz konusu ekosistem içerisindeki mali büyüklügü dikkate alındığında böylesi küresel ağın mikro ölçekteki örneği olarak Türkiye'nin kamu yönetişim modellerini belirlemesinin bir zorunluluk olduğu söylenmelidir. Aşağıdaki Şema 1 içerisinde, Türkiye'nin söz konusu dönem içerisinde nesnelerin interneti ekosistemi içerisindeki harcamaları yıl temelinde yer almaktadır.

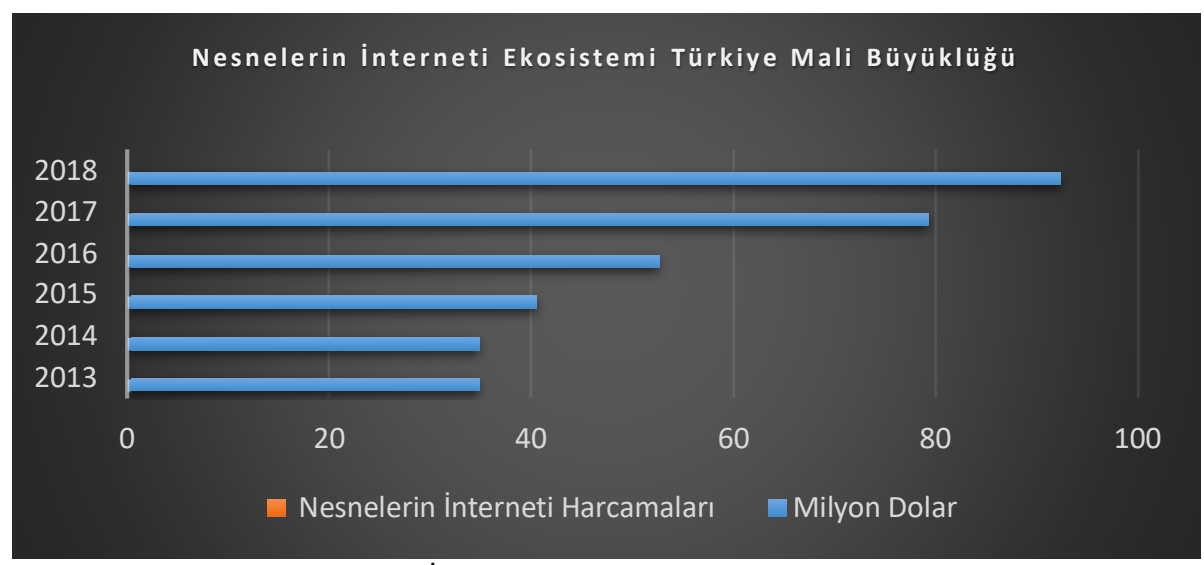

Şekil 1: Türkiye'de Nesnelerin İnterneti Ekosistemi Mali Büyüklüğü (Statista (2019:1).

1 “IOT Cybersecurity Improvement Act of 2019” (Congress, 2019:1). Yasa, 2019 yılında güncellenmiştir. 
Şekil 1 içerisinden bakıldığında 34,8 Türkiye koşullarında düzenli olarak genişleyen bir nesnelerin interneti pazarının varlığından söz edilebilmesinin olanaklı olduğu görülmektedir. 0 denli ki, en az harcamanın gerçekleştiği başlangıç dönemini oluşturan 2013 yılında dahi Türkiye genelinde 30 milyon doların üzerinde (34,8 milyon dolar) gerçekleșen harcamaların yıllar içerisinde istikrarlı olarak büyümesi dikkat çekmektedir. Bu çalışma henüz yazım aşamasında iken, en yüksek harcamanın 2018 yılında 90 milyon dolar (90,2 milyon dolar) seviyesinde gerçekleştiği ve yalnızca beş yıl içerisinde nesnelerin interneti ekosistemi harcamalarının Türkiye genelinde üç kat büyüklüğe eriştiği belirtilmelidir.

Nesnelerin interneti ekosisteminin Türkiye'deki mali büyüklügünü genişletmesinin yanı sıra ulaşımdan, "akıllı" şehir yönetişim modellerine, tarım ve eğitim sektörüne doğru geniş bir uzam içerisinde uygulama alanlarına sahip olması söz konusu ekosisteme dair genişleyen bir ilgiye tanıklık edilmektedir. Bu doğrultuda, kamu yönetişim modelleri için diğer gelişmekte olan ülkelere göre Türkiye'nin önemli bir farklılığından söz edilmesi anlamlı olacaktır. 0 denli ki; örneğin Hindistan ve Çin Halk Cumhuriyeti'nde nesnelerin interneti ekosisteminin daha çok devlet merkezli bir uygulama alanı olarak geliştiği belirtilmelidir. Örneğin, küresel olarak bilgi teknolojileri ve yazılım alanında ayırt edici bir yere sahip olan Hindistan, Hindistan Elektronik ve Enformasyon Teknolojileri Bakanlı̆̆ (Meity; 2019:1), eliyle nesnelerin interneti ekosistemi için beş önemli sütundan oluşan bir "nesnelerin interneti politikaları" uzamı belirlemiş ve Dijital Hindistan Programı'nın önemli bir bileșenine eklemlemiştir. Gelişmekte olan ülkelerde nesnelerin interneti ekosistemini, merkezi yönetişimin "stratejik" bir uzamı olarak değerlendiren önemli bir diğer örneğin ise Çin Halk Cumhuriyeti olduğu belirtilmelidir (Chen, Liu, Xu ve Hu, 2014:351). Ancak, Çin Halk Cumhuriyeti'nin nesnelerin interneti ekosistemini stratejik bir alan olarak tanımasından da önemli bir unsur, gelişmekte olan ülkeler içerisinde ilk kez gerçekleştiği üzere, 2010 yılındaki "Hükümet Çalışma Raporu'nun" ardından nesnelerin interneti ekosisteminin ulusal kalkınma planlarının odağında yer edinmesidir. 2012 yılında Endüstri ve Enformasyon Bakanlığı'nın “12. Beş Yıllık Kalkınma Planı” içerisinde yer aldığı üzere nesnelerin interneti teknolojileri, küresel ekonominin yeni bir dinamiği olarak değerlendirilmektedir. Bununla birlikte, Çin Halk Cumhuriyeti'nin nesnelerin interneti siyasa modelinde gerçekte küresel olarak gözlemlenen bir değerler dizisi değişiminin oldukça anlamlı bir örneğini oluşturduğu söylenmelidir. Nesnelerin interneti politikalarını önemli ölçüde etkileyen ya da yönetişim için gelişen yeni değerler dizisi kavrayışının bu doğrultuda ele alınması anlamlı olacaktır.

İnternet ve bileşen iletişim teknolojilerinin gelişimine koşut olarak; Hofmann, Katzenbach ve Gollatz'ın (2017:1413) işaret ettiği üzere, internet gibi merkezsiz ya da farklı ifade edildiğinde ulus devletlerin sınırlarının ötesinde bir uzam söz konusu olduğu için böylesi bir alanın yönetişimi gittikçe "küresel merkezler" eliyle üretilen politikaların belirleyiciliğinde ilerlemesi oldukça anlaşılabilirdir. Bununla birlikte; internet ve bileșen bilgi teknolojileri yönetişim modelleri içerisinden bakıldığında birbiri ile ilişskili olmakla birlikte bir dizi açıdan ayırt edilebilir iki önemli dönemin olduğu söylenmelidir. Nesnelerin internetine dair politika üretme süreci tam da 2006 yılından itibaren ayırt edilebilir bir siyasa belirleme yöntemi olarak görünürlük kazanan ikinci dönemi içerisinde görünürlük kazandığı söylenebilir. Hofmann, Katzenbach ve Gollatz'ın (2017:1412) "katılımcı koordinasyon olarak yönetişim" olarak isimlendirilecek bir süreç içerisinde, ulus devlete ilgili alandaki diğer paydaşlar arasında bir bakıma "koordinatör" statüsü atfedilmektedir. Yukarıda ana hatları ile değerlendirildiği üzere Çin Halk Cumhuriyeti gibi art alanında merkezi devlet kurumlarının etkisinin ağırlıklı olarak hissedildiği bir ülkenin dahi nesnelerin interneti ekosistemi yönetişim modelinde diğer paydaşların katılımını, bir politika belirleme yöntemi olarak kullanması dikkat 
çekmektedir. Küresel olarak nesnelerin interneti ekosistemine bağlı olan 1.5 milyar cihazın \%64'üne ev sahibi olup "dünyanın en büyük nesnelerin interneti pazarı" olarak (Estopace, 2019:1) dikkat çeken Çin Halk Cumhuriyeti'nin (Chinna Briefing, 2017), "Made in China" projesi önemli bir örnektir.

Türkiye'de ise, nesnelerin interneti ekosistemi ile ilişkili bir dizi yasal düzenlemeyi gerçekleştirdiği ancak bu denli geniş bir ekosistemi henüz ulusal kalkınma stratejisinin odağına alamadığı belirtilmelidir. Bununla birlikte Türkiye'de kamu politikaları içerisinde nesnelerin interneti ekosistemine dair, en azından bu çalışmanın yazım süreci içerisinde, henüz bir düzenleme yapılmamış olmasına rağmen ekosistem bileșenlerinin "IOT Türkiye" platformunu (https://ioturkiye.com, 2019) olușturması oldukça kayda değer bir çaba olarak öne çlkmaktadır.

Bilgi temelli ekonominin başat bir bileșeni olarak nesnelerin interneti ekosisteminin uzamı dikkate alındığında gelişmiş ülkelerden farklı olarak gelişmekte olan ülkelerin "olanaklar" kadar "tehditler" ile karşı karşıya kalabileceği belirtilmelidir. Örneğin Miazi, Rezzaque, Erasmus ve Zennaro'un (2016:5-7) erken dönemli çalıșmalarında belirledikleri üzere gelişmekte olan ülkeler en azından beș temel düzeyde engelle karşılaşmaktadır. Bu engeller şöyle maddeleştirilebilir: (a) Finansman Sorunları. Örneğin internet erişim ağ kapasitelerinin göreli olarak sınırlılığı ile ulusal internet altyapısının güçlendirilmesinde karşılaşılan mali sorunlarının yanı sıra bu çalışmanın yazarı tarafından öne sürüldügü üzere teknolojinin ulusal olanaklarla geliștirilmesinde yaşanan sorunlar bu açıdan önemli engeller olarak öne çıkmaktadır. (b) Altyapı Sorunları. Nesnelerin interneti ekosisteminin temel olarak ihtiyaç duyduğu üzere ulusal enerji ve altyapı sorunlarının gelişmiş ülkelerle karşslaştırıldığında, gelişmekte olan ülkelerde yaygın olarak karşılaşılan bir engeli oluşturmaktadır. (c) İnsan Kaynağı. Ülkelerin bilgi toplumuna dönüşüm süreçleri ile bilgi toplumu kazanımlarından yararlanabilmesinin önemli bir koşulu nitelikli işgücü ile bilgi temelli mesleki dönüşümüdür. Ancak, oldukça anlaşılabilir olduğu üzere, gelişmekte olan ülkelerin bu alanda sınırlı olanaklara sahip olması ve sınırlı olmakla birlikte var olan nitelikli emek gücünün gelişmiş ülkelere göç etmesi bir diğer önemli sorun alanını oluşturmaktadır. (d) Ulusal olanaklar yerine dışa bağımlılık. Nesnelerin interneti ekosisteminin ana omurgasını oluşturan teknolojinin, yukarıda da belirtildiği üzere, gelişmiş ülkelerin gelişmekte olan ülkelere bağımlılığını arttırmakta ve gelişmiş ülkelerin milli servetlerinin söz konusu teknolojik bağımlılık üzerinden gelişmiş ülkelere yönelmesine yol açmaktadır. Son olarak (e) Güvenirlilik ve Kişisel Bilgilerin Korunması. Çalışmanın önceki kısımlarında belirtildiği üzere; güvenirlilik, güven ve kișisel verilerin korunması her ne kadar tek başına gelişmekte olan ülkelerin değil gelişmiş ülkelerin de söz konusu ekosistem içerisinde karşılaștığı başat sorun alanlarından birisini oluştursa da gelişmekte olan ülkelerde teknolojide dışa bağımlılık ile birlikte değerlendirildiğinde genişleme potansiyeli yüksek bir engeli oluşturmaktadır.

Gelişmekte olan ülkelerin yukarıda sözü edildiği üzere nesnelerin interneti ekosistemi ile birlikte karşı karşıya kalabileceği potansiyel bir diğer sorun alanını ise Coletta ve Kitchin'in (2017: 4) değișen kent yönetişimi içerisinde değerlendirdiği üzere "algoritmik yönetişim" modellerinin kamu siyasası içesinde uygulanması oluşturmaktadır. Dijital teknolojilerin, gündelik yaşam pratikleri ve daha da önemlisi kamu yönetişimi içerisinde yer edinmesi ve edindiği yeri sürekli genişletmesi refakatinde; "büyük verinin" işlenmesi, sınıflandırılması ve yönetilmesi üzerine kurulan bir yönetişim modeline ihtiyaç duyulmaktadır. Bu doğrultuda, Türkiye'de bilgi teknolojileri ve yeni bir kamu yönetişim modeline ihtiyaç duyulduğu açıtır.

Kamu yönetişiminin uzamı ve aracı olarak nesnelerin interneti teknolojisini, karşılaştırmalı bir siyasa analizi içerisinden değerlendirerek Türkiye için bir dizi alternatif yönetişim modelini tartışmayı açmayı amaçlayan bu çalışmanın amaçları 
doğrultusunda Türkiye'de Bilim, Sanayi ve Teknoloji Bakanlığı tarafından hazırlanan (2018) "Türkiye'nin Sanayi Devrimi: Dijital Türkiye Yol Haritası" siyasanın incelenmesi anlamlı olacaktır. Çalışma, Türkiye için bir dizi alternatif yönetişim önerisinin yer aldığı sonuç bölümü ile tamamlanacaktır.

\section{Dijital Türkiye Yol Haritası Siyasasının Karşılaştırmalı Analizi}

Türkiye'nin, bilgi temelli kapitalizm çağında, ağırlıklı olarak, endüstri ve bileșen teknoloji yönetişim modellerini odağına alarak belirlediği "Dijital Türkiye Yol Haritası" siyasası farklı bir açıdan değerlendirildiğinde internet ve bileşen bilgi teknolojilerinin kamu yönetişimi gündemine nasıl da yeni bir değerler dizisini eklemlemesi açısından özel bir dikkat çekmektedir. Türkiye "2016-2019 Ulusal E-Devlet Stratejisi ve Eylem Planı" (Ulaștırma, Denizcilik ve Haberleșme Bakanlığı, 2016:139) stratejileri içerisinde "kamuda büyük veri ve nesnelerin interneti politikalarının geliștirilmesi ve yaygınlaștırılması" söylemine yer vermiștir. Bununla birlikte yeni ekosisteme dair henüz ayırt edici bir yol haritasını ilgili dönemde belirlememiștir. Bu nedenle çalıșma, "Dijital Türkiye Yol Haritası" çalışmasını değerlendirmektedir. Ancak, Türkiye'nin yukarıda yer alan ülke deneyimlerine göre bir farklılığının vurgulanması doğru olacaktır. Çalışmanın önceki bölümlerinde Avrupa Birliği ve Amerika Birleșik Devletleri öncelikli olmak üzere internet ve bileşen bilgi teknolojileri yönetişiminin kamu ve özel sektör arasındaki etkileşim tarafından önemli ölçüde etkilendiği belirtilmişti. Bu doğrultuda yukarıda sözü edilen siyasanın belki de önemli boyutlarından birisini siyasa sürecinin Bakanlık ve alandaki paydaşlar arasındaki ${ }^{2}$ koordinasyon ile geliștirilmiş olması oluşturmaktadır (Bilim, Sanayi ve Teknoloji Bakanlığı, 2018:12). Ancak, siyasanın bir dizi açıdan eleștirilebilmesi mümkündür. Önceki kısımlarda belirtildiği üzere, ülkelerin dijital dönüşüm modelleri örneğin Avrupa Birliği'nin "2020 Gündemi”, Çin Halk Cumhuriyeti’nin "2025 Stratejisi”, Almanya'nın "Endüstri 4.0 Planı" ya da Japonya'nın bilgi toplumu kavrayışını toplumun geneline yayarak daha ileri bir sosyal düzen olușturmayı amaçlayan "Toplum 5.0" modeli topyekûn bir toplumsal dönüşüm üzerine temellenmektedir. Japonya'nın "Toplum 5.0" yönetişim modeli bu açıdan dikkat çekmektedir. Toplumların gelişimini "avcı", "tarım", "sanayi", "bilgi" ve "5.0" toplumu olarak ayırt eden Japon Hükümeti'nin (http://www.japan.gov.jp, 2019), nesnelerin interneti ekosistemi içerisinde toplanan verilerin daha büyük bir "yapay zekâ" oluşturarak toplumun tüm kesimlerinin yararlandığı bir algoritmik yönetişim modeli kurmayı hedeflediği görülmektedir. $\mathrm{Bu}$ doğrultuda Japonya, nesnelerin interneti teknolojisini "ülke sanayisi" (monozokuri) ve algoritmik yönetişime uyumlu hale getirerek hem ürün kalitesinde artış hem de hammaddenin daha ucuz temin edilmesi ile iş TíM, kollarında kazanç artışını öncelikli olarak hedeflemektedir. Bununla birlikte nesnelerin interneti teknolojisini gündelik yaşamın "her köşesine" taşımayı amaçlayan Toplum 5.0 stratejisi ile gündelik yaşam pratiklerinde yeni bir algoritmik yönetişimin temelleri atılmaktadır.

Nesnelerin interneti ekosisteminin, sanayinin yanı sıra ülkelerin bilgi toplumuna dönüşüm süreçlerinin ötesine geçen boyutları dikkate alındığında, kamu politikalarının hem "uzamı" hem de "aracı" olarak yeni bir uzama işaret etmesi alternatif bir kamu yönetişim modeline duyulan ihtiyacını belirginleştirmektedir. Öte yandan, ülkelerin nesnelerin interneti ekosistemine dair kamu yönetişim modelleri ile Türkiye'nin dijital dönüşüm modeli arasındaki önemli bir diğer farktan daha söz edilmesi anlamlı

\footnotetext{
2 Sanayide Dijital Dönüşüm Platformu ismini taşıyan platform, Bilim Sanayi ve Teknoloji Bakanlığı'nın yanı sıra TOBB, TIM, TÜSİAD, MÜSİAD, YASED ve TTGV tarafından oluşturulmuştur. Raporda yer aldığı üzere söz konusu Platform, Almanya'nın sürdürdügü "Endüstri 4.0" Stratejisinden esinlenmiştir (Bilim, Sanayi ve Teknoloji; 2018:156-157).
} 
olacaktır. Gerçekten de, Çin Halk Cumhuriyeti 2015? Planı ya da Japonya Toplum 5.0 Stratejisi, Avrupa Birliği 2020 Gündeminde de görüldügü üzere, ülkelerin oldukça uzun süreli öngörülerini gerçekleştirmesine rağmen Türkiye'nin gelecek planlarını ise oldukça sınırlı olarak belirlemesi ülkenin bilgi toplumuna dönüșüm sürecini ve bu açıdan kazanımlarını bir bakıma tehlikeye atmaktadır. Böylesi bir "varsayımın" önemli açllımlarından birisi Türkiye'nin nesnelerin interneti ve bileşen bilgi teknolojileri alanında nitelikli işgücünün yetiştirilmesi, araştırma geliştirme merkezlerinin kurulması, ulusal bilişim altyapısının oluşturulması gibi önceliklerinin olduğunun vurgulanmasına rağmen (Bilim, Sanayi ve Teknoloji Bakanlığı, 2018:34) uzun süreli bir planlamanın olmamasıdır. Böylesi bir durumun ise, ilerleyen yıllarda ihtiyaç duyulan merkezlerin nasıl bir gelişim süreci içerisinde olabileceğinin öngörülememesine yol açmaktadır. Gerçekten de, teknolojinin yıllar içerisinde planlanamaması bilgi teknolojileri alanında ancak oldukça sınırlı bir dizi girișim ve projenin gerçekleştirilebilmesi sonucunu vermektedir. Așağıdaki Tablo 6 içerisinde, Türkiye'de Teknoloji Geliștirme (TGB) ile Araștırma Merkezleri'nde (ARGE) 2018 yılı içerisinde sürdürülen projelerin bilgi teknolojilerinin alt alanlarındaki dağılımına göre yer almaktadır.

\begin{tabular}{|c|c|c|}
\hline $\begin{array}{c}\text { Bilgi Teknolojisi } \\
\text { Dağılımları }\end{array}$ & $\begin{array}{c}\text { Teknoloji Geliştirme } \\
\text { Bölgelerinde Süren Projeler }\end{array}$ & $\begin{array}{c}\text { Araştırma Geliştirme } \\
\text { Merkezlerinde Süren Projeler }\end{array}$ \\
\hline $\begin{array}{c}\text { Yapay Zekâ } \\
\text { Büyük Veri ve İleri } \\
\text { Analitik }\end{array}$ & 94 & 22 \\
\hline $\begin{array}{c}\text { Sanallaștırma } \\
\text { (Arttırlmıs, Sanal } \\
\text { Gerçeklik) }\end{array}$ & 70 & 32 \\
\hline Bulut Bilișim & 62 & 15 \\
\hline Nesnelerin İnterneti & 46 & 8 \\
\hline Siber Güvenlik & 27 & 15 \\
\hline $\begin{array}{c}\text { Endüstriyel Otomasyon } \\
\text { ve Robotik Teknolojiler }\end{array}$ & 22 & 4 \\
\hline $\begin{array}{c}\text { Yeni Nesil (Akıllı) } \\
\text { Sensör Teknolojileri }\end{array}$ & 13 & 7 \\
\hline Eklemeli İmalat & 13 & 8 \\
\hline Toplam & 7 & $\mathbf{1 2 5}$ \\
\hline
\end{tabular}

Tablo 6: Türkiye'de 2018 Yllında Sürdürülen Bilgi Teknolojileri Projeleri (Bilim, Sanayi ve Teknoloji Bakanlı̆̆ı (2018: 59-60).

Türkiye'de ağırlıklı olarak Ankara, İstanbul, İzmir, Kocaeli ve Bursa'da yerleșik olan 322 Teknoloji Geliştirme Bölgesi ile 102 Araştırma Geliştirme Merkezi bünyesinde sürdürülmekte olan bilgi teknolojileri dağllımına göre sürdürülen projelerin yer aldığ Tablo 6'dan da izlenebileceği üzere nesnelerin interneti teknoloji üretimi, Teknoloji Geliștirme Bölgeleri'nde daha yoğundur. Bununla birlikte, Türkiye'nin dijital dönüșüm stratejisi söz konusu projelerdeki ulusal araștırma ve teknolojinin ulusal kaynaklarla ne denli geliştirilip, geliştirilemediğine dair herhangi bir açıklama yapılmamaktadır.

\section{Sonuç}

Gelişmekte olan bir ülke olarak Türkiye için, nesnelerin interneti ekosisteminin potansiyel gelişimi karşısında yeniden ele alınması gereken önerilerin bu doğrultuda önemli olduğu düşünülmektedir. Bu doğrultuda, Türkiye'de nesnelerin interneti yönetişimi için somut öneriler aşağıdaki gibi yer almaktadır. 
1) Nesnelerin interneti teknolojilerinin, ulusal bir yenilikçilik ağı oluşturularak geliştirilmesi bu doğrultuda önerilmektedir. Üniversiteler, araştırma merkezleri ve kamu yöneticileri öncelikli olmak üzere geniş katılımlı bir Ulusal Yenilikçilik Ağı, Türkiye'de sözü edilen ekosistemin ihtiyaç duyduğu araştırmaları ve politika uygulamalarını gerçekleștirme potansiyeline sahip olacaktır.

2) Nesnelerin interneti uzamının özellikle sağlık alanında yenilikçi uygulamaların geliştirilmesi için kullanılabilmesi, üstelik küresel düzeydeki bir salgın hastalığın bu denli etkili olmasının çok daha öncesinde bilinmekte olmasına rağmen, Türkiye'nin alan uzmanlarının desteğini alamadığı görülmektedir. Bu doğrultuda, Türkiye'de ön lisans, lisans, yüksek lisans ve doktora düzeyinde eğitim olanaklarının, programlarının, geliştirilmesi bu doğrultuda önem taşımaktadır.

3) Nesnelerin interneti kavrayıșı ile birlikte en azından küresel düzeyde gelișmiş olan yaratıcı kültür endüstrileri ekosistemi ile nesnelerin internetinin Türkiye özelinde bütünleștirilmesi çalışmanın bir diğer önerisini oluşturmaktadır. Örneğin, Türkiye'de henüz gelişme aşamasında olmakla birlikte "akıllı kent" yönetişimin öncelikle pilot bölgeler içerisinde uygulamaya koyulması ve yerelden ulusala doğru söz konusu yeni değerler dizisinin aşamalı olarak uygulanabilmesi böylesi bir bütünleşmenin somut sonucunu oluşturmaktadır.

4) Nesnelerin interneti teknolojilerinin, sanayi içerisindeki gelişme potansiyelinin geleneksel istihdam biçimlerine ve mesleklerine bir bakıma ciddi bir "rakip" olması karşısında eğitim politikalarının mesleki dönüşüme uyum sağlayacak denli yeniden yapılandırılması çalıșmanın bir diğer önerisini oluşturmaktadır.

5) Nesnelerin interneti ekosistemi ile birlikte önem kazanan bir diğer unsur ise "büyük verinin" işlenebilmesidir ki bu doğrultuda istatistik kurumlarının yeniden yapılandırılması söz konusu algoritmik yönetişim için önemli bir başlangıcı oluşturacaktır. Bu doğrultuda, Türkiye'de örneğin Bilgi Teknolojileri Kurumu ile birlikte üniversitelerin işbirliğinde "Büyük Veri Bankasının" oluşturulması toplumun geniş kesimlerinin gündelik yaşam pratiklerini önemli ölçüde kolaylaştıracaktır.

6) Bilgi teknolojilerinin gelişmesi ile birlikte önemli bir uğrak kamu yönetişiminin yeniden ele alınması üzerinden açılmaktadır ki; üniversiteler, araştırma merkezleri ve kamu yöneticileri arasında stratejik bir iletişimin kurulması çalışmanın diğer bir önerisini oluşturmaktadır.

Nesnelerin interneti ekosisteminin olanaklarından yararlanabilmek ve toplumsal dönüşümü sağlayabilmek oldukça zorlu bir sınavın verilmesini gerekli kılmaktadır ki, Türkiye eğitimli, dinamik ve nitelikli nüfusu ile böylesi bir zorlu sınavı başarmak zorundadır.

\section{KAYNAKÇA}

ANTHOPOULOS, L. G. (2017). "Smart Government: A New Adjective to Government Transformation or a Trick". Understanding Smart Cities: A Tool for Smart Government or an Industrial Trick? İçinde. Haz: Leonidas G. Anthopoulos. New York: Springer Puslishing. 263-283.

ARVIDSOON, A (2009). "The Ethical Economy: Towards a Post-Capitalist Theory of Value". Capital \& Class. Vol: 97. 13-29.

ATSINSON, D. Robert. (2014). "ICT Innovation Policy in China: A Review". The Information Technology \& Innovation. July 2014. 1-11.

ATZORI, Luigi, IERA, Antonio. ve MORABITO, Giacomo. (2010). "The Internet of Things: A Survey". Computer Networks. 31.May.2010. 1-19. 
BAUWENS, M. (2009). “Class and Capital in Peer Productions”. Capital \& Class. Vol: 97. 121-141.

Bilim, Sanayi ve Teknoloji Bakanlığı (2018). “Türkiye'nin Sanayi Devrimi: Dijital Türkiye Yol Haritası". http://www.sanayi.gov.tr. Erişim Tarihi: 18.09.2019.

CASTELNOVO, W, MISURACA, G, SAVOLDELLI, A. (2015). "Smart Cities

Governance: The Need for a Holistic Approach to Assesing Urban Participatory Policy Making". Social Science Computer Review. Vol: 34(6). 724-739.

CHATFIELD, A. T, REDDICK, G, C. (2019). "A Framework for Internet of ThingsEnabled Smart Government: A Case of IOT Cybersecurity Policies and Use Cases in U.S Federal Government". Government Information Quarterly. Vol: 36. 346-357.

CHEN, S; LIU, D; XU; H, WANG, H, HU, B. (2014). "A Vision of IoT: Applications, Challenges and Oppurtunities with China Perspective". IEEE Internet of Things Journal. Vol: 1(4). 349-359.

China Briefing. (2017). "Made in China 2025: Implications for Foreing Business". http://www.china-briefing.com. Erişim Tarihi: 16.09.2019.

COLETTA, C, KITCHIN, R. (2017). "Algorhythmic Governance: Regulating the "Hearthbeat" of a City Using the Intrenet of Things". Big Data \& Society. July-December. 1-16.

CONGRESS (2019). "IOT Cybersecurity Improvement Act of 2019".

http://congress.gov. Erișim Tarihi: 02.09.2019.

CONSTANCE, E. (2017). "The Internet of Things: Preparing for the Revolution".

Journal of Cyber Policy. Vol: 2(2). 152-154.

ESTOPACE, E. (2019). “GSMA: China is World's Largest IOT Market”. http://www.futureiot.tech. Erişim Tarihi: 16.09.2019.

FLEW, T. , WAISBORD, S (2015). "The Ongoing Significance of National Media Systems in the Context of Media Globalization". Media, Culture \& Society. Vol: 37(4). 620-636.

FUCHS, C. (2015). Dijital Emek ve Karl Marx. Çev: Tahir Emre Kalaycı ve Senem Oğuz. Ankara: Nota Bene Bilișim Yayınları.

GÖÇOĞLU, V. (2020). "Kamu Hizmetlerinin Sunumunda Dijital Dönüșüm:

Nesnelerin İnterneti Üzerine Bir İnceleme”. Manas Sosyal Araştırmalar Dergisi. Vol: 9(1). 615-628.

GÖYGÖNÜR, E, ŞENSOY, M, Mel, G. D. (2019). “Enabling Smart Environments Through Scalable Policy Reasoning and Internet of Things". WIREs Data Mining and Knowledge Discovery. Vol: 9(2). 1-20.

GRIFFOR, E, GREER, C; WOLLMAN, D; BURN, J, M. (2017). "Framework for Cyber-

Physical Systems: Volume I, Overwiev". http://www.nist.gov. Erişim Tarihi: 01.09.2019.

HOFMANN, J., KATZENBACH, C, GOLLATZ, K. (2017). "Between Coordination and Regulation: Finding the Governance in Internet Governance". New Media\&Society. Vol: 19(9). 1406-1423.

http://www.ab.gov.tr (2019). “Avrupa Birliği'nin Genişlemesi”. Erişim Tarihi:

02.08.2019.

http://www.ec.europe.eu (2016). "Definition of a Research and Innovation

Policy Leveraging Cloud Computing and IOT Combination”. Erişim Tarihi: 22.07.2019. http://www.ec.europe.eu (2019). "Policy: The Internet of Things". Erişim Tarihi:

22.07.2019.

http://www.ec.europe.eu. (2016). "Commission Staff Working Document:

Advancing The Internet of Things in Europe”. Erişim Tarihi: 25.07.2019.

http://www.ec.europe.eu. (2016). "Digitising European Industry”. Erişim Tarihi: 25.07.2019. 
http://www.ec.europe.eu. (2018). "Data Protection: Rules for the Protection of Personal Data Inside and Outside the EU". Erişim Tarihi: 29.07.2019.

http://www.ec.europe.eu. (2019). “Digital Single Market”. Erişim Tarihi:

24.07.2019.

http://www.eugdpr.org (2019). "The EU General Data Protection Regulation is the Most Important Change in Data Privacy Regulation in 20 Years". Erişim Tarihi: 29.07.2019

http://www.eur-lex.europe.eu. (2018). "Regulation EU 2016/679 Of the European Parliament and of the Council”. Erișim Tarihi: 29.07.2019.

http://www.internetworldstats.com (2017). "Internet Stats and Facebook Usage in Europe June 2017 Statistics". Erișim Tarihi: 20.12.2017.

http://www.ioturkiye.com. (2019). "Iot Türkiye: Türkiye'nin En Büyük

Nesnelerin İnterneti Ekosistemi”. Erișim Tarihi: 17.09.2019.

http://www.japan.go.jp (2019). "Realizing Society 5.0". Erișim Tarihi: 18.09.2019.

http://www.meity.gov.in. (2019). "IOT Policy Document". Erișim Tarihi:

16.09.2019.

http://www.resmigazete.gov.tr (2016). "Kișisel Verilerin Korunması Kanunu".

Erişim Tarihi: 30.07.2019.

INTEL (2019). "Policy Framework for the Internet of Things".

http://www.intel.com. Erişim Tarihi: 28.08.2019.

Internetworldstats (2019). "Internet Stats and Facebook Usage in Europe Mach

2019 Statistics”. http://www.internetworldstats.com. Erişim Tarihi: 12.07.2019.

ITU (2018). "Policies and Regulations Pertaining to IOT". http://www.itu.int.

Erişim Tarihi: 28.08.2019.

BAN, M. C ve AKSU, O. (2020). “A Model for Big Spatial Rural Data Infrastructure in Turkey: Sensor-Driven and Integrative Approach". Land Use Policy. Vol: 91

(February). 1-15.

KARATGOZIANNI, A, MICHAELIDES, G. (2009). "Cyberconflict at the Edge of the Chaos: Cryptohierarcies and Self Organization in the Open Source Movement".

Capital\&Class. Vol: 97. 143-157.

KONG, L, WOODS, O. (2018). "The Ideological Alingnment of Smart Urbanism in Singapore: Critical Reflection on a Political Paradox". Urban Studies. Vol: 55(4). 679701.

KRANENBURG, R. V. (2010). "A Poor or a Rich Internet of Things; Our Choice Now: A Look into the Future and the Meaning of the Internet of Things". Vision and Challenges for Realising the Internet of Things. Ed: Herald Sundmaeker, Patrick Guillemin, Peter Friess ve Sylvie Woelffle. Brusells: European Commission: Information Society and Media DG Publishing. 25-32.

MAPLE, C. (2017). "Security and Privacy in the Internet of Things". Journal of Cyber Policy. Vol: 2(2). 155-184.

MIAZI, S. N, REZZAQE, A, ERASMUS, Z, ZENNARO, M, BAGULA, A. (2016).

"Enabling the Internet of Things in Developing Countries: Opportunities and Challanges". http://www.researchgate.net./publication/311757185. Erişim Tarihi: 18.09.2019.

MURDOCK, G. (2017). “Communication, Crissi and Control: Economies, Ecologies and Technologies of Digital Times". Medijska Istrazivanja. Vol: 23(2). 17-33.

NIST (2016). "Cyber-Physical Systems". http://www.nist.gov. Erişim Tarihi: 31.08.2019. U

ORSI, C (2009). "Knowledge Based Society, Peer Production and the Common Good". Capital\& Class. Vol: 97. 31-51. 
PICARD, V (2007). “Neoliberal Visions and Revisions in Global Communications Policy From NWICO to WSIS". Journal of Communications Inquiry. Vol:31(2). 118-139.

PUPPIS, M. (2008). "National Media Regulations in the Era of Free Trade: The Role of Global Media Governence". European Journal of Communication. Vol: 23(4). 405424.

RIFKIN, J. (2015). Nesnelerin İnterneti ve İşbirliği Çağı. Çev: Levent Göktem. İstanbul: Optimist Yayınları.

RIGI, J. (2013). "Peer Production and Marxian Communism: Contours of a New Emerging Mode of Production". Capital \& Class. Vol: 37(3). 397-416.

SANTUCCI, G (2010). "The Internet of Things: Between the Revolution of the Internet and Metamorphosis of Objects". Vision and Challenges for Realising the Internet of Things. Ed: Herald Sundmaeker, Patrick Guillemin, Peter Friess ve Sylvie Woelffle. Luxembourg: Publication Office of European Union. European Commission Information Society and Media Dividions. 11-25.

SENNET, R. (2017). Eşit Olmayan Bir Dünyada Saygı. Çev: Ümmuhan Bardak. İstanbul: Ayrıntı Yayınları.

SHERMAN, J. (2018). "US Federal IOT Policy: What You Need to Know".

http://www.tripwire.com. Erișim Tarihi: 31.08.2019.

STATISTA (219). "Retail Iot Spending in Turkey from 2013 to 2018".

http://www.statista.com. Erişim Tarihi: 7.09.2108.

TRAK (2019). "First Ever Internet of Things Policy Document Released by Indian Government". http://www.trak.in. Erişim Tarihi: 04.07.2019.

Ulaştırma, Denizcilik ve Haberleşme Bakanlığı. (2016). "2016-2019 Ulusal eDevlet Strateji ve Eylem Planı". http://www.e-devlet.gov.tr. Erişim Tarihi: 02.03.2020.

UMAR, A, ÇALIȘ, C. (2019). "Centralized Smart Governance Framework Based on IOT Smart City Using TTG-Classified Technique". IEE 16th International Conference on Smart Cities: Improving Quality of Life Using ICT \& IOT and AI (Honet-ICT). New York: Charlette. 157-160.

WEBER, V (2018). "Linking Cyber Strategy With Grand Strategy: The Case of the United States". Cyber Policy. Vol: 3(2). 236-257.

YÜKSEL, A. E. B (2016). "Nesnelerin İnternetinin Hukuki Yönden İncelenmesi”. Dokuz Eylül Üniversitesi Hukuk Fakültesi Dergisi. Cilt: 17(2). 113-139.

\section{Summary}

This theoretical debate has aimed to open a discussion on the cyber-physical synergies namely the internet of things and its new ecosystem. Although the past two decades have witnessed a gradually interest by the growing body of researchers' addressed Western world, especially Euro-American metropole centres, a few studies focussed emerging countries. Nevertheless, for the aim of the present article one of the most important debate, macro political and macro-economic inquiries on the internet of things ecosystem as if forgotten or the blind spot of the ongoing studies. Therefore; the present article, through the lens of comparative political analysis, endeavours a governance model for this newly established ecosystem in the concrete case of Turkey. The analysis of the present article reveals these aspects of the internet of things ecosystem. (1) which factors that shape the smart, or specifically, algorithmic governments in practice for developed countries. Regarding Turkey's long march to the European Union's candidacy, the present article addressed European Union and United States of America's public policies. (2) how new information technologies affected the policy circumstances both developed and developing countries' experiences in the new ecosystem. (3) the practices and outcomes of 
the internet of things' policies both developed and developing countries public policy making practices. In this sense, the present article has divided into five sections. After the introduction section which is presents this study's research questions and theoretical basis, the following sections are deal specifically with the comparative political analyses in the new ecosystem. In this sense, following sections attempt to the analyses of internet of things policies and public policy making practices in the European Union, United States of America and some of the developed countries' such as Japan and South Korean policies. In this sense, as mentioned earlier, these sections addressed strengthens and weakens of the ongoing public policies for the improving of public policy model in the case of Turkey. Although the new public policy making process, so-called "algorithmic" governance, implemented profound realm such as traffic coordination, human health management or security system for the retired models of the countries', apparently need some serious refinement in order to the appropriate operations in the new ecosystem. For example, the cyber security policies and artificial intelligence policies seem need some revisions. Arguably the new concept of public policy making states the presence of the main aspect of the internet of the things ecosystem. Yet, the new model of policies' such as "smart governance" or "algorithmic" management essential some profound revisions such as the re-making of cyber security or the other aspects of the new ecosystem. After debated the main aspects and major political tensions in the new policy circumstances, the following sections directly focused on the concrete case of Turkey and She's policy making trends. In order to a proper understanding of this new ecosystem, and more significantly than this aspect, to improving a new policy models for Turkey, I scrutinized Turkey's national development plans, specifically $11^{\text {th }}$ National Development Plan, and Turkey's national internet of things ecosystem. In my argument; with more than 80 million populations and approximately 250 million USD Dollars expenditure per year, Turkey has become one of the most remarkable case for the emerging countries in the new ecosystem. Yet, as debated earlier, Turkey's national policies seems unconcerned to improving a new policy for internet of things ecosystem. To a large degree, this is very unexpected. While many developing countries, such as India and Serbia, attempts to developing very distinctive policies in the new ecosystem, Turkey, as in the many developing countries' policy experiences, do not improving a distinct policy. In my argument this hesitant situation, to a large degree, retardant the knowledge society transformations in Turkey. At this point, I was offered a number of alternative models for Turkey's internet of things ecosystem such as establishment of a new national regulation authorities in which the new authority consisted of previous national authorities such as Radio and Television Supreme Council and Information Technologies and Communication Institution. In this sense, Office of Communication's organization model is representing a new regulation models for the governmentality of internet of things ecosystem.

At the final section, I analysed a new alternative governmental models for Turkey's new ecosystem. Although Turkey's national policy circles seems do not attempt an improve of new policy and alternative governmentality models for knowledge societies, Turkey has got the power of this kind of capabilities. 